\title{
REVISIÓN DE LA FIEBRE DE MAYARO POR LOS ÚLTIMOS ACONTECIMIENTOS EN CUSCO - PERÚ
}

\author{
Revision of the Mayaro fever for last events in Cusco - Perú

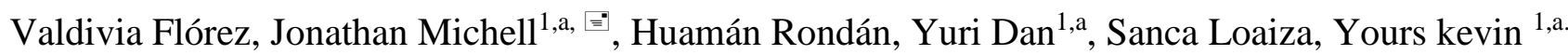 \\ 1 Escuela profesional de Medicina, Universidad Andina del Cusco, Cusco, Perú. \\ a Estudiente de Medicina \\ Đsfx100pre@hotmail.com
}

Citar como: Valdivia, JM., Huaman YD., Sanca, YK. (2018). Revisión de la fiebre de mayaro por los últimos acontecimientos en Cusco - Perú (carta al editor). Rev Yachay, 7(1), 501-502.

Recibido: 16-09-2018; Aceptado 07-12-2018

Sr Editor

Si deseamos tener un control de calidad en la salud, primero tenemos que estar informados de las diversas enfermedades que se producen en nuestra región. Es el caso de la «fiebre de Mayaro», es una enfermedad producida por el virus de Mayaro (MAYV) que pertenece a la familia Togaviridiae y al género Alphavirus (grupo A de los arbovirus).

Se transmite por la picadura de mosquitos hembras infectados con este virus, principalmente del género Haemagogus spp. La enfermedad se caracteriza con una rápida elevación de la temperatura corporal, pero este cuadro febril es de corta duración —entre tres y siete días - y se resuelve por sí solo. Ello va acompañado con malestar general, cefalea, artralgias, mialgias, mareos, náuseas, dolor abdominal, pérdida de apetito; que posteriormente, se desarrollan erupciones en la piel, principalmente en el tórax y extremidades. En algunos casos se presenta dolor de garganta, congestión nasal, tos y algunas hemorragias (Zúñiga Carrasco, Iván R.; Caro Lozano, Janett, 2017 ).

Epidemiología: En los últimos años, el Perú ha estado en una lucha constante contra las enfermedades transmitidas por vector, se confirmó la circulación de un nuevo virus en la región del Cusco, se trata del virus Mayaro (MAYV), que produce la denominada fiebre del Mayaro. La Red de Servicios de Salud La Convención, registra un total de 35 casos confirmados de Mayaro: 29 de ellos confirmados por ELISA IgM, 3 por PCR-RT y 3 resultados indeterminados, que fueron confirmados por compatibilidad clínica. En estos 35 casos podemos determinar que 21 son varones y 14 son mujeres, teniendo en cuenta que la edad promedio es de 42,7 años; siendo así el paciente más joven de 18 años y el más longevo de 77 años.

Este incremento de la fiebre de Mayaro en la región del Cusco, se registró en pacientes que residen en la cuenca del Chirumbia (distrito de Quellouno), o haya realizado un viaje a la región de Madre de Dios, en los cuales se identificaron 3 pacientes que refieren haberse desplazado a Puerto Maldonado en la región de Madre de Dios, entre enero y febrero de 2018 por motivos de trabajo y por la visita del papa Francisco ( Placeres Hernández, José F.; De León Rosales, Lázaro C.; De León Otero, A.; Águila Cedeño, O.; Mesa Viera, Y. , 2018).

\section{Sintomatología de la fiebre de Mayaro en el brote de Quellouno, La Convención 2018}

Artralgias $89,3 \%$, mialgias $82,1 \%$, cefalea $78,6 \%$, malestar general $75 \%$, fiebre $64,3 \%$, lumbalgia $60,7 \%$, escalofríos $60,7 \%$, rash (erupción cutánea) $50 \%$, mareos $39,3 \%$, tos $21,4 \%$, náuseas $17,9 \%$, vómitos $14,3 \%$, dolor abdominal $14,3 \%$, conjuntivitis $10.7 \%$, epistaxis $7,1 \%$, estreñimiento $7,1 \%$, dolor ocular $3,6 \%$, fotofobia $3,6 \%$, edema $3,6 \%$, ictericia $3,6 \%$, gingivorragia $3,6 \%$, parestesias 3,6\%. (Óp. Cit.); (DIRESA, 2018). 
Diagnóstico:El virus Mayaro, puede aislarse de la sangre por crecimiento en células Vero o C6/36. Se dispone de RT-PCR y ELISA, así como de un análisis para la detección de IgM específica mediante ELISA de captura de anticuerpos. Hay una PCR genérica para alphavirus y otra específica para el MAYV, que es positiva en los primeros días de la enfermedad cuando el paciente es virémico. A partir del 3.er día podemos detectar IgM específica, y después IgG con varias técnicas serológicas (EIA, IFA, HI y NT). La serología IgM puede permanecer positiva 3 meses, y la IgG persiste años. (Azevedo, Silva, Carvalho, Rodrigues, Nunes, Neto, Monteiro, Peixoto, Chiang, Nunes y Vasconcelos, 2009).

Tratamiento: Control de la temperatura con medios físicos, antipiréticos — tales como el paracetamol—e hidratación oral a base de electrolitos o, en caso de estar hospitalizado, el lactato de Ringer (Cabezas,César; Donaires, Fernando, 2017).

\section{Referencias bibliográficas}

Placeres Hernández, José F.; De León Rosales, Lázaro C.; De León Otero, A.; Águila Cedeño, O.; Mesa Viera, Y. (set.-oct. de 2018) Necesidad de incrementar los conocimientos y las acciones de prevención sobre la fiebre mayaro y la fiebre amarilla. Revista Médica Electrónica, vol. 40 ( n. ${ }^{\circ}$ 5). Recuperado el 20 de junio de 2018, de http://scielo.sld.cu/scielo.php?script=sci_arttext\&pid=S1684-18242018000501647

Azevedo, Silva, Carvalho, Rodrigues, Nunes, Neto, Monteiro, Peixoto, Chiang, Nunes y Vasconcelos (noviembre de 2009) Mayaro Fever Virus, Brazilian Amazon. Emerging Infectious Diseases, 15(11), 1830 - 1832. Recuperado el 2 de noviembre de 2018, de https://wwwnc.cdc.gov/eid/article/15/11/pdfs/09-0461.pdf

Cabezas,César; Donaires, Fernando (28 de junio de 2017) Enfoque sindrómico para el diagnóstico y manejo de enfermedades infecciosas agudas en situaciones de emergencia. Rev. Perú Med. Exp. Salud Pública, 34(2), 316 - 322 . doi: 10.17843/rpmesp.2017.342.2836

DIRESA (agosto - setiembre de 2018) Situación epidemiológica de fiebre del Mayaro. (G. R. Cusco, Ed.) Boletín Epidemiológico, 18(35), 18. Recuperado el 2 de noviembre de 2018, de: http://www.diresacusco.gob.pe/inteligencia/epidemiologia/boletines/2018/35-2018.pdf

Zúñiga Carrasco, Iván R.; Caro Lozano, Janett (Enero-Marzo de 2017) Virus Mayaro: una nueva amenaza para el continente Americano. Revista Latinoamericana de Infectología Pediátrica, Volumen 30(Número 1), pp. 12-14. Recuperado el 2 de noviembre de 2018, de http://www.medigraphic.com/pdfs/infectologia/lip-2017/lip171c.pdf
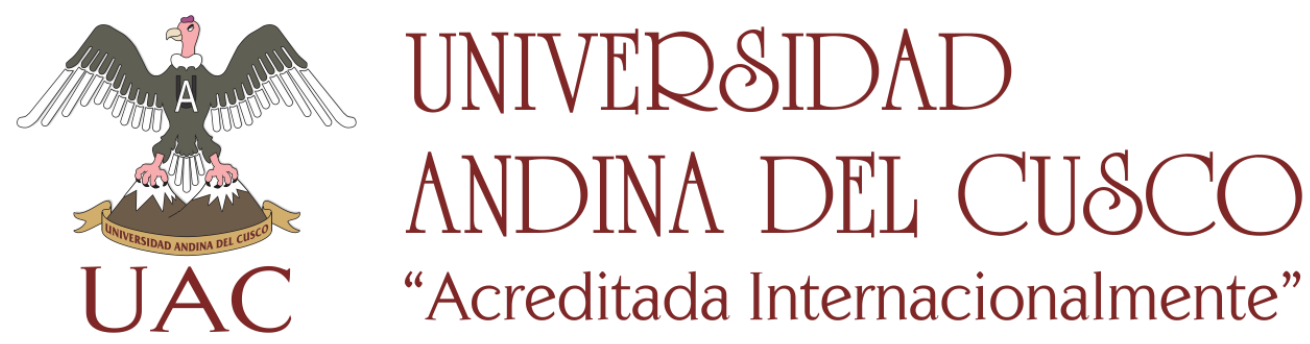